\title{
The Modern Problem of Inner Personal Resource Provision for Professional Development of Future Psychologists: Motivational Aspect
}

\author{
Lada Mazai \\ Department of Psychology and Social Work, Vinnytsia State Pedagogical University, Vinnytsia, \\ Ukraine
}

Email: lada.mazai@vspu.edu.ua

\begin{abstract}
The article presents a theoretical analysis of the problems of resource provision for professional development of future psychologists with an emphasis on one of its main components, namely the motivational aspect. Latter is considered from the standpoint of the phenomenological approach and the presence of existential meanings in the structure of personal professional motivation. In particular, we have specified the concept of resource provision in professional development and outlined the study relevance in the modern transformational conditions. Modern transformational society creates new conditions for professional development for specialists of socionomic professions. In particular, the requirements for the professional competencies of psychologists and their professional training are increasing. Additional complications in the professional development process are created by today's online format of learning. This specific creates a problem of professional development motivational provision at its early stages.
\end{abstract}

Keywords: Resource Provision; Professional Development; Future Psychologists; Inner Motivation; Professional Choice; Phenomenological Approach.

Modern scientific and technological progress with its globalization trends in the world economy determines the formation of high competition in the labour market, which in turn increases the requirements for the competence of young professionals. Today, the arsenal of the necessary qualities of any professional should include soft skills, which cover a wide range of communication and leadership skills, the ability to work in a team, flexibility and tolerance to situations of uncertainty. All this creates new conditions for professional training and professional development. In particular, the development of information and communication technologies offers new formats of education and self-education, which in turn require a high level of personal motivation.

No less important and relevant issue in this topic is the personality of the psychologist, as a representative of socionomic professions, whose aim is to ensure the psychological and emotional well-being of society. In this case, we should also notice the importance of inner and outside resources for the personal and professional development of these specialists. Thus, an important role in the effective perfomance of any psychologist is played by his internal personal resources, which create support for his motivation and resilience to client's trauma.

The future psychologist's readiness to the longterm professional training and development of their properties necessary for practical activities is one of the considerable components of their motivation for professional development. At the same time, today we can observe the focus on achieving quick success in young people. This trend does not bypass future psychologists in the process of their professional development, which causes a rapid loss of motivation in their professional training in the third year of higher education. Therefore, we consider the necessity to pay scientific attention to the problem of the motivational component of the resource provision for professional development of future psychologists.

We should note that the issue of professional development is not new among the world and Ukrainian scientific community. Thus, the issues of professional self-determination and identity were paid attention to by Vondrachek (1990), Povarenkov (1991), Holland (1997), Blushtein (1998), Ermolaieva (1998, 2004), Shneider (2001), Ivanova (2004), Abdulaieva (2014). The psychological features of professional readiness were considered in the scientific works of Kotyk (1967), Diachenko and Kandybovych (1976), 
Platonov (1984), Ponamorenko (2004). The motivational factor as a source of personality activity in professional development was studied by Shchadrykov (1982), Klimov (1996), Maryshchuk (2001), Ilin (2006) and others. In recent years, the variety of personal factors of professional readiness, which can serve as determinants of successful professional development have been focused by Klimov (1996), Derkach (1998, 2004), Maryshchuk (2001) and Zeier (2003, 2006). Also, it is necessary to mention Druzhylov's $(2010,2011)$ dissertation researche of an individual resource as bases of formation of professionalism. Various aspects of professional development as a systemic and complex process were also studied by Parsons (1909), Roe (1956), Siuper (1957, 1971), Mosey (1963), Holland (1968), Kuzmina (1990), Markova (1996), Poviakel (2003), Maksymenko (2003), Bolotov (2005), Anisimov (2011, 2013), Mitina (2014), Kremen (2015) and others. The problems of personal and professional self-realization became the subject of scientific works of Antsyferova (1969), Abulkhanova Slavska (1991), Ananiev (2001), Leontiev (2001), Kokun (2012) and others. However, none of the mentioned studies touched upon the issue of resource provision for professional development of future psychologists, which makes this topic relevant.

This article represents a brief overview of the theoretical analysis of the current problem of internal resource provision for professional development of future psychologists, in particular, its motivational component. With the help of the theoretical investigations of previous scientific studies and our own reflection on this problematic we create a theoretical model of research subject and identified diagnostic criteria for further empirical research on this issue.

Before proceeding to the presentation of the main material, it is necessary to dwell on the specification of the definition of the concept of resource provision of professional development.

The problem of resource development, selfactualization, health, etc. as a personal and psychological potential has been the subject of many scientific research and has been developed in methodologically different concepts and theories. In particular, special attention was paid to the definition of the essence and content of resource provision in the framework of humanistic psychology. V. Frankl believed that the personal potential and resource capability of human life and self-determination depend on the search for meaning (the so-called logos) of existence and ultimately in its presence (Frankl, 1959, 1962, 1984, 1992, 2004).

We also should emphasize that in modern psychological science, the prevailing approach is to define the concept of "resource" in the categories and content of stress and coping theories. For instance, in S. Hobfall's resource concept of stress, resources are defined as something valuable for a person that helps him/her to successfully adapt to difficult life situations (Hobfall, 1993). The scientist considered such kinds of resources as material objects (financial security, housing, clothing, transport, etc.) and immaterial (desires, goals); external (social support, family, friends, work, social status) and internal intrapersonal factors (self-esteem, professional competence, optimism, self-control, life values, belief system, etc.); psychological and physical conditions; willing, emotional and energy characteristics that are necessary to maintain health or play role of means to achieve personally important goals. Moreover, it is necessary to note that Hobfall has allocated two types of resource capacity in his study. They are external and internal, where the first one is more subject to its definition as conditions of realization of personal internal potential (Hobfall, 1993).

Division has also been suggested by V. A. Bodrov and N. E. Vodopianova. According to N. E. Vodopyanova, resources are internal and external components that contribute to psychological stability in stressful situations; these are emotional, motivational and willing, cognitive and behavioural constructs that actualize the individual ability to adapt to stressful work and other life situations. They are tools (means) that are used to transform the interaction with a stressful situation (Vodopyanova, 2009). V.A. Bodrov defines the concept in such way: "Resources are those physical and spiritual capabilities of man, the mobilization of which ensures the implementation of the program and ways (strategies) of behaviour to overcome or limit stress" (Bodrov, 2006) and distinguishes their two classes - personal resources and environmental resources, or psychological and social. 
If to give attention to the specification of our work problem, it is important to mention the research of those authors who highlighted the aspect of personal potential or resources in terms of career growth or professional self-realization. Thus, K. K. Platonov used the term "potential vocation", that characterized the individual ability to a certain professional activity. During this activity, the potential vocation may become relevant or illusory (Platonov, 1984). A. K. Markova in the structure of internal conditions for success in professional activities identified a system of personal qualities that would comply with the requirements of the profession and determine the possibility of professional development, as well as the individual resource capacity of the particular person (Markova, 1996).

Scientists L. H. Pochebut and V. A. Chyker in their analysis of the specifics of career success, use the concept of "personal potential" (Pochebut \& Chyker, 2000). They suggest that in the absence of the necessary personal professional qualities, with low motivation, external locus of control, high anxiety, self-doubt and emotional instability, unconstructive attitudes towards the achievement (fear of failure, unrealistic goals, unwillingness to take risks, focus on oneself, not on activity), the achieving of career success becomes impossible or is threatened. According to this statement, if a subject wants to develop a positive result in his professional development, their personal potential must include features that will be inverse to the properties listed above (Pochebut \& Chyker, 2000).

Thus, after having analyzed the basic concepts and theories of defining the concept of resource provision, we were convinced of the multifaceted content and essence of this topic. Various properties and manifestations of person's character, behaviour, cognitive and emotional spheres, etc. can be the elements of his/her resource provision for professional development. As it can be observed in different kinds of scientific research dedicated to the mentioned issue, the success of the process of professional development and career growth requires such parameters as a high level of adaptability, stress resistance, internal locus of control, self-regulation, strong motivation, professionally important properties, certain selfdetermination, etc.

However, the problem of our investigations requires a detailed clarification of the problem of professional development resource provision of future psychologists, whose practical activity is fraught with a high risk of emotional and professional burnout and require a significant level of self-efficacy and motivation.

The general theoretical discourse in the area of future psychologists' professional development and their internal personal resource provision and motivation, as its component, prompts the idea to consider this issue in terms of phenomenological analysis and psychological and systemic approach.

The phenomenology of consciousness demonstrates that the objects of the environment exist because the subject's attention is drawn to them. What acquires significance for the "Ego" and what its intentionality is addressed to, can serve as a subject of individual reflection or scientific exploration. Therefore, the question of professional development and its resource provision, in general, should begin with the peculiarities of the perception of these phenomena by the individual "Ego".

The actual individual intention to these objects of social relationships, endowing them with personal existential content is a deep primary link in the internal stimulation of the subject to professional activity. It is presented in search of the meaning of being through the need for selfactualization, self-realization, belonging to a social group, the satisfaction of which occurs through professional self-determination, self-identification and professional self-realization. The focus on the actualization of one's self-concept and the expansion of self leads the individual to understand the importance of performing the socially useful and economically sound creative activity. At this point, as subconscious motivational mechanisms of professional development, we can consider several needs identified by representatives of different psychological areas (psychodynamic, humanistic, existential) - the search for meaning in life, confirmation of their existence, belonging to society and positive approval of their "Ego", sublimation of libido impulses and enjoyment through legalized culture activities, reducing guilt. At this level, hypothetically, the subject seeks answers to the question of who he is, what he desires and what he wants to achieve?

It is necessary to remind that the reflection on professional self-determination begins at the 
border of preadolescence and adolescence and is included in the process of forming the basic vitally which is necessary for the psychological aspect of identification. By this time, an approximate idea of the individual about himself should be formed, namely, their self-concept and the system of selfassessment, which also determine the set of value orientations and the subject's orientation in a particular professional activity plane.

The process of professional self-determination includes the individual orientation in information about certain professions, and, therefore, already at this stage, there is probably an image of the profession to which the young person wants to belong. At the same time, the correlation process of the properties of personal self-concept with the image of the profession is taking place, as a result of which the subject makes a conclusion about their capabilities and abilities to the profession and further professional training.

During the professional education, the person specifies the image of the profession, tests the ability to work in the chosen profession, creates an ideal image of themselves in the profession, outlines the goals and prospects of work and what an individual should do to achieve high results. E. P. Korablyna notes that already in the third year of university studying students begin to form more professional self-awareness, which is embodied in creating a structure of psychological readiness to perform professional activities, the image of the profession becomes more detailed and integrates components of time orientation and quality content filling (Korablyna, 2004).

The presence of such a professional image determines the emergence of another important property of the internal resource provision of professional development, namely professional self-esteem, which is used to correlate the components of the self-concept with the requirements to the person as a specialist or professional. Differences in the images of the professional self-concept create space for selfimprovement, outline the goals of professional training and activities, set the level of claims and prove or disprove the need for professional selfrealization. In fact, personal self-esteem determines the degree of self-respect and makes it possible to formulate answers to such stimulating questions as "What is my "Ego" aimed at?" and "Do I have enough strength, opportunities and abilities for self-realization, in particular in the chosen professional activity?", "What should I do for professional development or career growth or/and professionalism?". Motives for success or avoidance of failures that directly depend on the modality of the individual self-esteem and his/her experience of obtaining positive approval of the person's activities from other important people become relevant at this stage of professional reflection. In particular, the level of performance of an individual in the process of professional development and the quality of professional selfrealization will depend on what the subject expects from the activity and the efforts made in it success or failure.

It is necessary to emphasize that the process of professional development is dynamic. Even with strong internal motives for entering the university and choosing a speciality, the applicant can go through a number of transformational stages of his idea of the profession, his place in it, development potential, opportunities for professional and career self-fulfilment, etc. There are also cases of disappointments in the image of the profession, which are provided by its inadequate vision before professional education, the contrast between the existing individual psychological properties, abilities and real requirements of professional activity.

In our opinion, moral and ethical standards and rules of psychological practice, and with them, a high level of responsibility for professional activity, put enormous pressure on the subjective sense of individual professional suitability and competence. Thus, a number of researchers such as E.P. Korablyna, L. E. Năstasă and A.-M. Cazan note that students-psychologists of the third year of university studying or even already graduated have doubts about their own professional effectiveness, their coping-strategic resources in overcoming stress (Korablyna, 2004) (Năstasă \& Cazan, 2013). They experience fear and anxiety before the actual work with clients, uncertainty about the conditions and requirements of the profession, etc. Therefore, we believe that the dynamics of professional motivation and training of future psychologists as one of the components of the resource provision in their professional development requires more detailed research.

As a result of theoretical analysis of the problem of internal resource provision of future 
psychologists' professional development, it was developed a four-level model of internal motivational component of resource provision of future psychologists' professional development, which reflects elements of personal intention and motivational and willing structure (F. 1.).

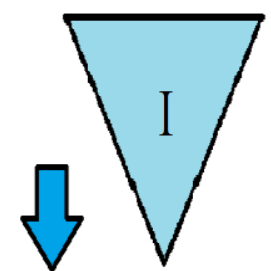

The need for self-determination, self-realization and self-actualization, belonging to society, search for pleasure, etc.

Individual meaning and content of need as a resource for professional self-determination

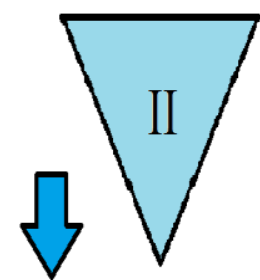

Professional self-determination: the choice of profession, the formation of the image of the profession, the ratio of the self-concept components with the requirements of professional training and activities

The image of the profession as a goal anda resource for professional training

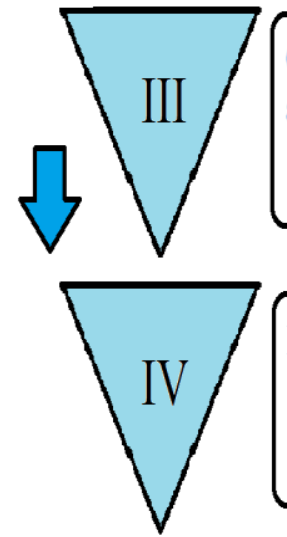

Concretization of the image of the profession, the formation of professional self-awareness, assessment of personal ability to perform professional activities and professional self-image

Professional self-esteem and the level of aspirations as a resource for professional self-improvement

Realization of personal knowledge, abilities and skills, inclinations and potential in counselling practice

Motives for success / avoidance of failures, professional reflection and self-esteem as resources of professional development; professional self-identification, self-awareness and competence as a resource of professional development.

Figure 1: Four-level model of intra-motivational component of resource provision of future psychologists' professional development.

Guided by the basic existential and intentional needs, the subject forms its own system of motives, values, interests and goals. In fact, motives determine the search for what is valuable to the individual in order to meet personal needs. The structure of values determines the range of individual interests, which may or may not include professional development and related areas of activity. In this incentives hierarchy, goals play the role of the object of the direction of the subject's time perspective and determine the ways how he can achieve them and realize his needs, values and interests.

Such a scheme helps to form a general clear systemetic structure of probable motivational elements of resource provision for professional development of future psychologists. However, we should note that such a construct is external to the individual subjectivity in his/her activity and in particular professional activity. In our opinion, the individual "self-concept", which integrates images of possible options for personal self-realization in life can be the internal stimulus to the emergence of such an external scheme. Among possible options, we can single out the professional selfconcept with self-identification, which includes also real self, ideal self, past self, actual self and future self in the profession. All these images play both roles of self-esteem stimulus and motives on every particular stage of personal professional development, which is a way to professional selfrealization as a goal. At the same time, self-esteem is used as means of correlation of selected selfstates and the definition of properties that need to be improved or formed to achieve high professional standards or professional ideal. The level of general and professional self-esteem will determine the level of individual aspirations, its focus on achieving success in professional development or avoiding failure. Moreover, for successful self-improvement, the subject's selfesteem should not be too low or too high, so as not to provoke stagnation of activity in educational and further professional activities. 
The external structure of intra-personal stimulation or moytivation of professional development can be considered as a reflection of the conscious level of self-analysis, which is the result of the internal (subconscious) level and, in addition, belongs to its manifestation and can be used as an element of a probable structure of diagnostic parameters. The levels of such structures functioning are conditionally defined, as they can pass from the subconscious register to the conscious one and vice versa.
In conclusion, such a general concept of the motivational component of the resource provision for professional development of future psychologists can be used to determine the diagnostic criteria of this subject for further research. Scientific attention should be focused on the future psychologists' motives of professional choice, entering university, studying, the presence or absence of the need for self-realization, its degree, a level of self-esteem and aspirations, orientations to succeed or avoid failure.

\section{REFERENCES}

[1] Alia I. Sheikh, Derek L. Milne, Bryony V. MacGregor. (2007). A model of personal professional development in the systematic training of clinical psychologist. Clinical Psychology and Psychotherapy. 14, PP. 278-287. Published online in Wiley InterScience (www.interscience.wiley.com). https://doi.org/10.1002/cpp.540

[2] Bodrov, V. A. (2006). Problema preodoleniya stressa. Chast' 2. Protsessy i resursy dlya preodoleniya stressa [The problem of overcoming stress. Part 2. Processes and resources for coping with stress.] Psikhologicheskiy zhurnal. T.27. №2. PP. 113-122. [in Russian].

[3] Buiakas, T. M., \& Mykheev, V. A. (2016) Fenomenologicheskaya germenevtika professional'nogo razvitiya [Phenomenological hermeneutics of professional development]. Moscow: University Bulletin. Series 14. Psychology. No. 3. PP.17-24 . [in Russian]. https://doi.org/10.11621/vsp.2016.03.16

[4] Druzhilov, S. A. (2010). Individual'nyy resurs cheloveka kak osnova stanovleniya professionalizma: monografiya [Individual resource of a person as the basis for the formation of professionalism: monograph]. Voronezh: Nauchnaya kniga. 240 p. [in Russian].

[5] Frankl, V. (2004).Man's Search For Meaning: The classic tribute to hope from the Holocaust. London. Sydney. Auckland. Johannesburg: Rider. 160 P.

[6] Hobfoll, S. E., \& Lilly, R. S. (1993). Resource conservation as a strategy for community psychology. Journal of Community Psychology. № 21. PP. 128-148. https://doi.org/10.1002/1520-6629(199304)21:2\%3C128::aidjcop2290210206\%3E3.0.co;2-5

[7] Kalashnikova, S. A. (2011). Lichnostnyye resursy i psikhologicheskoye zdorov'ye cheloveka: sootnosheniye soderzhaniya ponyatiy. [Personal resources and psychological health of a person: the ratio of the content of concepts]. Gumanitarnyy vektor. No. 2 (26). PP. 185-189.[in Russian].

[8] Kazaryan, P.A. (2016). Profesiynyy rozvytok maybutn'oho psykholoha [Professional development of the future psychologist]. Aktual'ni problemy psykholohiyi. Zbirnyk naukovykh prats' Instytutu psykholohiyi imeni H.S. Kostyuka NAPN Ukrayiny. Tom 7. Ekolohichna psykholohiya Vyp. 42. Kyiv. P.112-119. [in Ukrainian].

[9] Kokun, O. M. (2012). Psykholohiya profesiynoho stanovlennya suchasnoho fakhivtsya: monohrafiya.[Psychology of professional development of a modern specialist: monograph]. Instytut psykholohiyi imeni H.S. Kostyuka NAPN Ukrayiny. Kyiv: DP «Inform.-analit. ahenstvo» 200 p. [in Ukrainian].

[10] Korablyna, E. P. (2004). Fenomenologicheskaya model' professional'noy samorealizatsii psikhologakonsul'tanta [Phenomenological model of professional self-realization of a counselor psychologist]. Psikhologicheskiye problemy samorealizatsii lichnosti [Psychological problems of personality self-realization] St. Petersburg: Izdatel'stvo SPbGU. Issue. 8. PP. 48-62. [in Russian].

[11] Laura Elena Nastasa, Ana-Maria Cazan. (2013). Personal and professional development of beginner psychologists. $3^{\text {rd }}$ World Conference on Psychology, Counselling and Guidance. Procedia - Social and Behavioral Sciences 84. 781-785.

[12] Markova, A. K. (1996). Psikhologiya professionalizma [Psychology of professionalism]. Moscow: Mezhdunarodnyy gumanitarnyy fond «Znaniye».12 P. [in Russian].

[13] Nancy S. Elman, William N. Robiner, Joyce Illfelder-Kaye. (2005). Professional development: training for professionalism as a foundation for competent practice in psychology. Professional Psychology: Research and Practice, Vol. 36, No. 4, 367-375. https://doi.org/10.1037/0735-7028.36.4.367

[14] Platonov, K. K. (1984). Kratkiy slovar' sistemy psikhologicheskikh ponyatiy [A Brief Dictionary of the System of Psychological Concepts]. Moscow: Vyshe.174 P. [in Russian].

[15] Pochebut, L. H., \& Chyker, V. A. (2000). Organizatsionnaya sotsial'naya psikhologiya [Organizational social psychology]. St. Petersburg: Rech'. 298 P. [in Russian]. https://doi.org/10.31085/9785392305674-2020-552 
[16] Shneider, L. B. (2004). Professional'naya identichnost': teoriya, eksperiment, obucheniye [Professional identity: theory, experiment, training]. Moscow: Izdatel'stvo Moskva. psych.-soc. in-ta. 600 P. [in Russian].

[17] Tharenou, P. (2001). The relationship of training motivation to participation in training and development. Journal of Organizational Psychology, 74, 599-621. https://doi.org/10.1348/096317901167541

[18] Vodopianova, N. E. (2009). Psikhodiagnostika stressa [Psychodiagnostics of stress]. St. Petersburg: Piter. 336 P. [in Russian].

Received on 06-09-2021

Accepted on 21-09-2021

Published on 04-10-2021

(C) 2021 Lada Mazai; Licensee ATSK Publishers.

This is an open access article licensed under the terms of the Creative Commons Attribution Non-Commercial License (http://creativecommons.org/licenses/by-nc/3.0/) which permits unrestricted, noncommercial use, distribution and reproduction in any medium, provided the work is properly cited. 